\title{
Analysis of Fish Samples as a Biomarker of Levels of Pollutants In Ona River, Ibadan, Oyo State, Nigeria
}

\author{
${ }^{1}$ Adegbola, Rachael Adebola, ${ }^{2}$ Adewuyi, Gregory Olufemi and ${ }^{3}$ Adekanmbi, \\ Adewumi Iyabode \\ 1 \& 3 Chemistry Department, The Polytechnic, Ibadan \\ ${ }^{2}$ Chemistry Department, University of Ibadan, Ibadan
}

\begin{abstract}
Clarias gariepinus and Cyrinus carpio was analysed to determine the levels of heavy metals using Buck Scientific Atomic Absorption spectrophotometer and phthalate esters using reversed phase High Performance Liquid Chromatography. Digestion and extraction of the analytes were conducted using standard procedures. The result indicated that the levels of chromium $(\mathrm{Cr})$, cadmium $(\mathrm{Cd})$, lead $(\mathrm{Pb})$ were not detected in all samples, nickel (Ni) was detected in two locations; an agricultural research farm and an industrial estate. While zinc (Zn) was detected in all samples ranging from 0.68 and $1.03 \mu \mathrm{g} / \mathrm{g}$ in Clarias gariepinus and $0.92 \mu \mathrm{g} / \mathrm{g}$ in Cyrinus carpio. The percentage recoveries were between 52.2 and $91.13 \%$. DBP was below detectable level in all samples. DMP, DPP and DEP were identified with highest concentrations in three locations while DMP was detected in only Clarias gariepinus and not in Cyrinus carpio. DEP was found only in one location with the lowest concentration in Clarias gariepinus. Fish samples from the river are contaminated with phthalate esters. Long time consumption can lead to numerous health issues.
\end{abstract}

\section{Introduction}

Contamination of the aquatic systems by heavy metals and some organic pollutants such as phthalate esters has caused a lot of concern both in developed and developing countries in recent times. Many industrial and agricultural processes have contributed to the contamination of fresh water systems thereby causing adverse effects on aquatic biota and human health (Wang, 2002).

Pollution of the aquatic environment with heavy metals and other organic compounds has become a worldwide problem during recent years, because they are indestructible and most of them have toxic effects on organisms (Mac Farlane and Burchett, 2000). Among environmental pollutants, metals and phthalate esters were of particular concern, due to their potential toxic effect and ability to bioaccumulate in aquatic ecosystems (Censi et al.,2006).

Heavy metal concentration in tissues of aquatic animals reflects path exposure via water and/or food; it can demonstrate the current situation of the animals before toxicity affects the ecological balance of populations in the aquatic environment. Studies on heavy metals in rivers, lakes, fish and sediments (Ayoola, 2000; Begum et al., 2005; Fernandes et al.,2008) have been a major environmental focus especially during the last decade. The consequences of excessive bioaccumulation of these heavy metals in fishes include: hemotoxicity, ferotocixity and depressed chemosensory abilities (Sogiento, 2008). In human beings these effects have been identified as clinical carcinogenesis, neurotoxic, nephrotoxic, ferotoxic and tetratogenic syndrome which has been associated with chronic or sub chronic exposure of man to the heavy metals via oral ingestion, dermal or respiratory absorption (Kordon, 2005).

There has been growing interest in the unusual ubiquity of phthalate in the environment (Fatoki and Verno, 1990; Fatoki and Ogunfowokan, 1993) and their wide range of toxicological characteristics (Blount et al., 2000). Phthalates have possible tetratogenic and carcinogenic effect. The main route of exposure to phthalates is via water use as these chemicals find their way into the water system through effluent discharges and leaching from waste dumps, and through several diffuse sources (WHO, 2003).

Phthalate esters have been considered as environmental pollutants for marine ecosystem. Phthalate esters have been detected in not only water, soil, air and foods, but also in animal organs. Environmental fate processes of phthalic acid esters are driven by their hydrophobicities and ability to partition and adsorb to organic phases. Sorption to terrestrial soils plays an important role in reducing the mobility of these chemicals and may significantly delay their entry into groundwater and aquatic systems. The most significant environmental loss processes for phthalate occurs through bioaccumulation.

Several researches have been carried out on the level of heavy metal contaminants in rivers and streams in Nigeria. But there was a dearth in the research on the concentration of phthalate esters and heavy metals in fishes in the Ona River. Clarias gariepinus and Cyrinus carpio from Ona river in Ibadan Metropolis Nigeria are frequently and largely eaten in Ibadan Metropolis, so their phthalate esters and toxic metal content should be of 
Analysis Of Fish Samples As A Biomarker Of Levels Of Pollutants In Ona River,Ibadan, Oyo State,

concern to human health. The present research therefore, carried out in view of the scarcity of information about phthalate esters and heavy metals in the marine organisms from this region.

The objective of this research was the assessment of the concentration of phthalate esters and heavy metals in fish samples in Ona River as a biomarker of the level of pollutants.

Ona river is one of the major rivers in Ibadan Metropolis. It is a habitat to some aquatic animals Clarias gariepinus and Cyrinus carpio inclusive. The river runs through some agricultural farms, domestic settlements and Oluyole Industrial Estate. Effluents of some of the industries that found their way into the rivers contributes to high levels of contaminants in fishes sold in the open markets which will eventually find their way into the tables of homes around the metropolis.

The following phthalate esters: diethyl phthalate (DEP); dimethyl phthalate (DMP); dibuthyl phthalate (DBP) and diphenyl phthalate (DPP) and also the following heavy metals: chromium (Cr); lead (Pb); Zinc ( $\mathrm{Zn})$ and Cadmium (Cd) in the fish samples (Clarias gariepinus and Cyrinus carpio) was analysed and results reported.

\section{EQUIPMENTS}

\section{Materials And Methods}

Buck Scientific Model version (210/211) VGP Atomic Absorption Spectrophotometer (AAS) was used for the analysis of heavy metal. The phthalate ester was analysed using High Performance Liquid Chromatography from the Central Laboratory of Obafemi Awolowo University, Ile-Ife, Osun State. HPLC model was AKTA HPLC; with ambient temperature using Acetonitrile/water (90/10) as the Mobile Phase, Split Ratio is $90: 10$, the flow rate is $1.0 \mathrm{ml} / \mathrm{min}, \mathrm{UV}$ at $254 \mathrm{~nm}$ was used as the detector, the stationary column was $\mathrm{C}_{18}$ $\left(\mathrm{S}_{5} \mathrm{ODS}_{2}\right)$ Octadecyl silane and the column lenght/diameter was $25.0 \mathrm{~cm} \times 3.0 \mathrm{~mm}$.

\section{SAMPLING}

Fish (Clarias gariepinus and Cyrimus carpio) samples were used for analysis. The samples were identified at the Fishery Department, University of Ibadan. Sampling was done between the 14th and the 21st of June 2010. The samples were picked when the river is just been filled with fresh water. Sampling time was between 5:30am and 7:45am and 4:30pm and 7:45pm daily. The fish samples were migrant in nature.

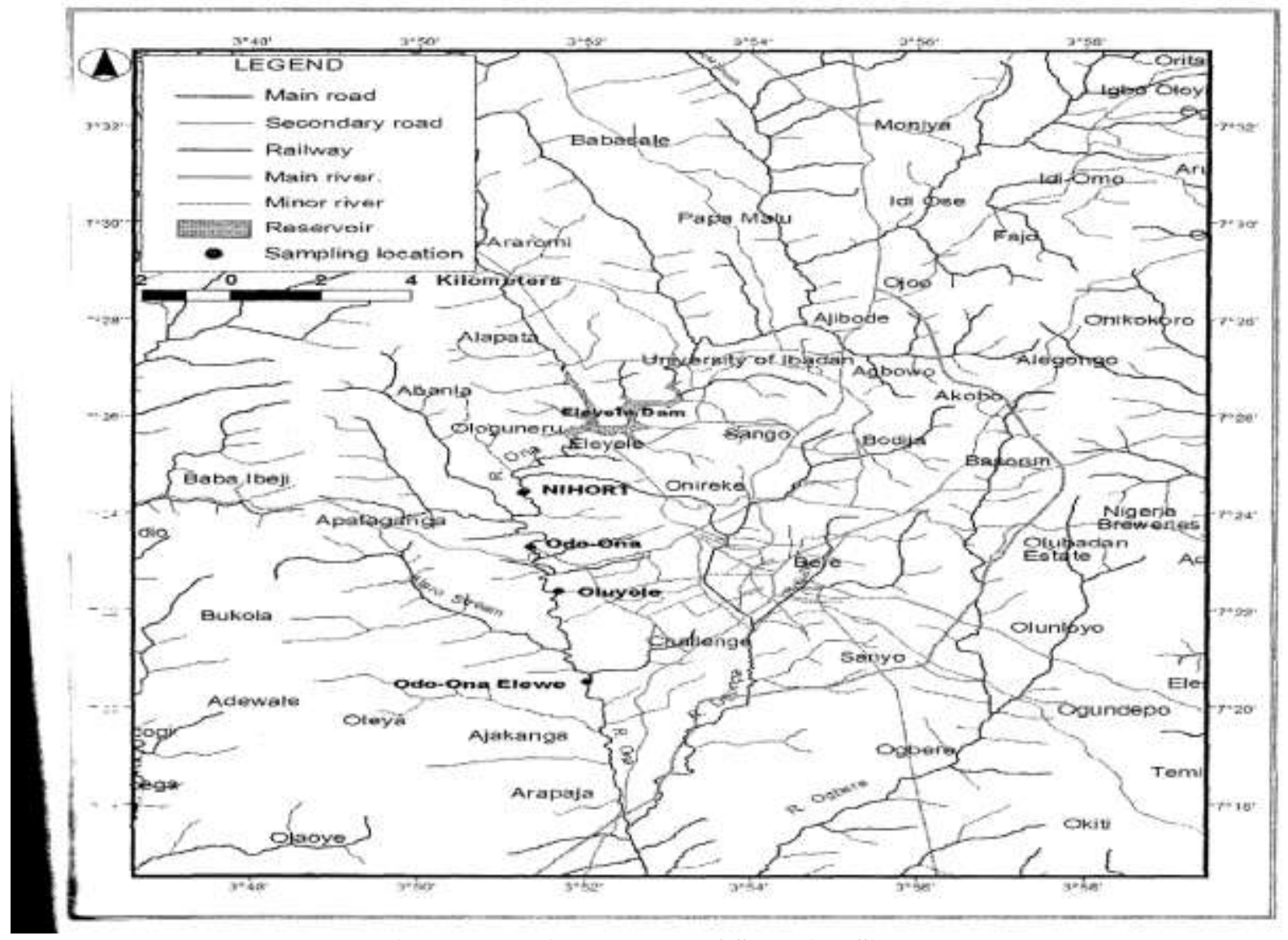

Figure 1 showing the Map of Sampling Sites

Source: Geography Department, University of Ibadan, Ibadan. 
Analysis Of Fish Samples As A Biomarker Of Levels Of Pollutants In Ona River, Ibadan, Oyo State, POPULATION AND SAMPLING LOCATIONS

Cyrinus carpio $\left(\mathrm{F}_{1}\right)$ was collected from one of the site (Nihort Research Farm approximately $7^{\circ} 24^{\prime} \mathrm{N}$ ) because Clarias gariepinus was not present in the section of the river while Clarias gariepinus $\left(\mathrm{F}_{2}, \mathrm{~F}_{3}\right.$ and $\left.\mathrm{F}_{4}\right)$ were collected from three other sites (Gada Odo-Ona approximately $7^{\circ} 24^{\prime} \mathrm{N}$, Oluyole Industrial Estate approximately $7^{\circ} 22^{\prime} \mathrm{N}$ and Odo-Ona Elewe approximately $7^{\circ} 20^{\prime} \mathrm{N}$ ).

\section{Sample Collection and Preservation of Fish Samples}

Samples of live Cyrinus carpio and Clarias gariepinus were procured by direct harvesting with the assistance of fishermen. Samples were collected from up-stream, mid stream and down-stream of the river within South West and Ido Local Government Areas of Ibadan Metropolis. Each sample was representative of the concentrations of phthalate esters and heavy metals discharged in the environment. Samples for phthalate esters were caught in glass containers with sufficient water while heavy metals were collected in plastic containers. All the samples were taken to the laboratory for preparation prior further analysis.

\section{PREPARATION OF REAGENTS AND EXTRACTIONS}

\section{Phthalate Esters Determination}

All reagents used were of redistilled analytical-reagent grade and distilled water.

\section{Analysis of Fish (Hot Extraction method)}

The scales and fins of the fish were removed with the use of new surgical blade; the samples were cleaned up. Enough dorsal tissues were removed for the analysis. The samples were dried and homogenised, $5.0 \mathrm{~g}$ each of the samples was packed into soxhlet extractor timbles. Phthalate in each sample was extracted for eight hours by the use of soxhlet extractor. Residue of each extract was filtered through a filter paper. The solvent is recovered by re-distillation. The filtrate was dried over anhydrous $\mathrm{Na}_{2} \mathrm{SO}_{4}$, to remove water. The extracts were taken with hexane.

For phthalate esters, standard stock solutions of DEP, DMP, BBP and DnBP were prepared $(\mathrm{lmg} / \mathrm{ml})$ in hexane and stored at $4^{\circ} \mathrm{C}$. Working solutions were prepared by appropriate dilution of solutions.

Calibration graphs for each standard against instrumental response were developed by running High Performance Liquid Chromatography (HPLC).

\section{Clean-up Procedure for all Extracted Samples}

For the cleanup method, $12.5 \mathrm{~g}$ of activated alumina prepared in slurry form on hexane, was packed in a column. The residue in $2 \mathrm{mls}$ of DCM above was chromatograph through the packed column. Phthalates were eluted successfully from the column with $20 \mathrm{ml}$ of hexane and $30 \mathrm{~m} 1$ ethyl acetate. The ethyl acetate eluted was concentrated to $1 \mathrm{ml}$ by purging with nitrogen gas. $1 \mathrm{ml}$ acetonitrile was added to the residue for HPLC analysis. The extracts were kept in refrigerator below $4^{\circ} \mathrm{C}$ until instrumental analysis was conducted.

\section{Analysis of Phthalate Esters}

Portions of these solutions were analyzed for phthalate esters (DEP, DMP, BBP and DnBP) by use of High Performance Liquid Chromatography (HPLC).

\section{Response Factor and Quality Assurance Study}

Preparation of sample of materials, sampling procedures, reagents and materials, extraction and analytical procedures were carefully quality controlled. Quality assurance study was carried out in term of recoveries of phthalate in order to ascertain the efficiency of the extraction and the analytical procedure since no certified reference material was available. The recovery was done by extracting organic-free water spiked (Vitali et al., 1997, Guidoth et.al., 2000) with 0.1ml of phthalate mixture of (DMP, DEP, DPP and DBP) containing the internal standard at a concentration of 100ppm.

After extraction, concentration and clean-up, $0.1 \mathrm{ml}$ of the extract was diluted with the acetonitrile to $10 \mathrm{ml}$ using $10 \mathrm{ml}$ standard flask. $2.0 \mathrm{ml}$ of the diluted extract was injected on the HPLC. The response factor, concentration of phthalate esters and percentage recovery were obtained.

\section{Heavy Metals Determination \\ Analysis of Fish (Hot Extraction method)}

Five gram $(5.0 \mathrm{~g})$ each of the homogenised samples was weighed into a $500 \mathrm{ml}$ Kjeldhal flasks. $10 \mathrm{ml}$ each of concentrated trioxonitrate $(\mathrm{V})$ acid and tetraoxosulphate (VI) acid was added to the samples in the Kjedhal flasks respectively. The samples were then digested for several hours on a hot plate in a fume cupboard until a clear solution was obtained. They were then cooled and filtered.

The filtrates were transferred to $100 \mathrm{ml}$ volumetric flasks and its content made up to $100 \mathrm{ml}$ mark by addition of distilled water (AOAC, 1990). 
Analysis Of Fish Samples As A Biomarker Of Levels Of Pollutants In Ona River,Ibadan, Oyo State,

For each metal (chromium, nickel, lead, zinc and cadmium) a stock standard of 1000ppm were prepared, and then from the stock solution, 10ppm, 5ppm, lppm concentrations were prepared for each metal. Serial dilution was carried out in order to minimise errors that arise from pipetting too small volumes.

Calibration graphs for each standard against instrumental response were developed by running the Atomic Absorption Spectrophotometer (AAS).

\section{Analysis of Heavy Metals}

Portions of these solutions were analysed for chromium, nickel, lead, zinc and cadmium using Buck Scientific Model version (210/211) VGP AAS Atomic Absorption Spectrophotometer.

\section{Statistical Analysis}

The result obtained from the HPLC and AAS methods (for phthalate esters and heavy metals) was compared with the results and the tools for the analysis are:

1. Unpaired data t-test at $95 \%$ confidence level was carried out to test their level of significance.

2. ANOVA was used to compare the result of the analysis using the two instruments (HPLC and AAS) for each contaminant.

\section{Results}

Analysis of data and results were presented below:

Table 4.1 showing the mean concentration of heavy metals in fish samples in $\mu \mathrm{g} / \mathrm{g}$

\begin{tabular}{lllll}
\hline & $\begin{array}{l}\mathbf{H F}_{\mathbf{1}} \\
\text { Nihort }\end{array}$ & $\begin{array}{l}\mathbf{H F}_{\mathbf{2}} \\
\mathbf{G a d a}\end{array}$ & $\begin{array}{l}\mathbf{H F}_{\mathbf{3}} \\
\text { Oluyole }\end{array}$ & $\begin{array}{l}\mathbf{H F}_{\mathbf{4}} \\
\text { Elewe }\end{array}$ \\
\hline Zinc & 0.92 & 0.68 & 0.78 & 1.03 \\
Chromium & ND & ND & ND & ND \\
Cadmium & ND & ND & ND & ND \\
Lead & ND & ND & ND & ND \\
Nickel & 0.02 & ND & 0.033 & ND \\
\hline
\end{tabular}

ND means not at detectable concentration

From table 4.1 chromium, cadmium and lead were not detected in all the four fish samples Nickel was not detected in samples $\mathrm{HF}_{2}$ and $\mathrm{HF}_{4}$ which were Claria gariepinus while nickel was detected with the least concentration of $0.02 \mu \mathrm{g} / \mathrm{g}$ in Cryrinus carpio and a concentration of $0.03 \mu \mathrm{g} / \mathrm{g}$ in Clarias gariepinus . Zinc was detected in all the fish samples with $\mathrm{HF}_{4}$ having the highest mean concentration of $1.03 \mu \mathrm{g} / \mathrm{g}$ followed by $0.78 \mathrm{ug} / \mathrm{g}$ and $0.68 \mathrm{ug} / \mathrm{g}$ respectively in Clarias gariepinus $\mathrm{HF}_{3}, \mathrm{HF}_{2}$, while Cryrinus carpio had $0.92 \mu \mathrm{g} / \mathrm{g}$ mean concentration.

Result showing the HPLC peaks for the standard, concentration of phthalate esters identified and the recovery study were presented below:

Table 4.2 showing values for Retention time, \% Recovery, Response factor and Limit of Detection for fish samples

\begin{tabular}{lllll}
\hline Phthalate Esters & $\begin{array}{l}\text { Retention time } \\
\text { (minutes) }\end{array}$ & \% Recovery & $\begin{array}{l}\text { Response } \\
\text { factor }\end{array}$ & $\begin{array}{l}\text { Limit of } \\
\text { Detection } \boldsymbol{\mu g} / \mathbf{l}\end{array}$ \\
\hline DMP & 3.14 & 91.13 & 2.21 & 0.72 \\
DEP & 3.36 & 877.02 & 2.11 & 0.57 \\
DBP & 4.27 & 52.22 & 1.72 & 1.83 \\
DPP & 3.74 & 90.29 & 5.02 & 1.16 \\
\hline
\end{tabular}

From table 4.2 the retention time for DMP, DEP, DBP and DPP were 3.14, 3.36, 4.27 and 3.74 minute respectively in the samples. The percentage recovery was between $52.22 \%$ and $91.13 \%$ respectively for fish samples. The response factors for DPP, DMP, DEP and DBP were 5.02, 2.21, and 1.72 respectively. The limit of detection of the instrument for DBP was $1.83 \mu \mathrm{g} / \mathrm{l}$, DPP; $1.16 \mu \mathrm{g} / \mathrm{l}$, DMP was $0.72 \mathrm{ug} / \mathrm{l}$ and DEP was $0.57 \mathrm{ug} / \mathrm{l}$.

Table 4.3 showing concentration of phthalate esters in fish $(\mu \mathrm{g} / \mathrm{g})$

\begin{tabular}{lllll}
\hline Phthalate esters & 1st Run & 2nd Run & 3rd Run & Mean \\
\hline Nihort: $\mathrm{F}_{1}$ & & & & \\
DPP & 181.27 & 171.22 & 181.87 & 178.12 \\
DMP & BDL & BDL & BDL & BDL \\
DEP & BDL & BDL & BDL & BDL \\
DBP & BDL & BDL & BDL & BDL \\
Gada $: F_{2}$ & & & &
\end{tabular}


Analysis Of Fish Samples As A Biomarker Of Levels Of Pollutants In Ona River,Ibadan, Oyo State,

\begin{tabular}{lllll}
\hline DMP & 194.68 & 192.40 & 166.88 & 184.65 \\
DPP & BDL & BDL & BDL & BDL \\
DEP & BDL & BDL & BDL & BDL \\
DBP & BDL & BDL & BDL & BDL \\
Oluyole $: \mathrm{F}_{3}$ & & & & \\
DMP & 102.35 & 111.30 & 102.44 & 105.36 \\
DPP & BDL & BDL & BDL & BDL \\
DBP & BDL & BDL & BDL & BDL \\
DEP & BDL & BDL & BDL & BDL \\
Elewe $: \mathrm{F}_{4}$ & & & & \\
DMP & 278.26 & 265.30 & 288.22 & 277.26 \\
DPP & 418.42 & 4.22 .30 & 400.68 & 413.8 \\
DEP & 37.12 & 37.05 & 36.98 & 37.05 \\
DBP & BDL & BDL & BDL & BDL \\
\hline
\end{tabular}

BDL = Below detection limit

From table 4.3 the mean score for DPP was $178.12 \mu \mathrm{g} / \mathrm{g}$, DBP, DMP and DEP were not below detection limit of the instrument in Cyrinus carpio samples picked at Nihort Research Farm.

Clarias gariepinus sample from Gada area had mean score of $184.65 \mathrm{ug} / \mathrm{g}$ for DMP while DPP, DBP and DEP were below detection limit of the instrument. Oluyole Clarias gariepinus sample contained DMP, DPP with mean scores of $105.36 \mu \mathrm{g} / \mathrm{g}, 21.15 \mu \mathrm{g} / \mathrm{g}$, and other esters below detection limit of the instrument. Elewe Clarias gariepinus samples have mean score of $277.26 \mu \mathrm{g} / \mathrm{g}, 413.8 \mu \mathrm{g} / \mathrm{g}$.nd $37.05 \mu \mathrm{g} / \mathrm{g}$ for both DMP, DPP and DEP respectively DBP was below detection limit of the instrument.

Statistical analysis of fish analysis shows that there is no significant difference between the means of concentration in the location used $\left(\mathrm{F}_{\mathrm{cal}}=0.371<\mathrm{F}_{\mathrm{tab}}=2.84, \mathrm{p}>0.05\right)$. The means concentration at Nihort was 44.530, Gada was 46.163, Oluyole was 31.627 while that of Elewe was 69.315 these were not statistically significant at 0.05 level of significance. Also, there was no significant difference between the means Phthalate esters used $\left(\mathrm{F}_{\mathrm{cal}}=1.431<\mathrm{F}_{\text {tab }}=2.84, \mathrm{p}>0.05\right)$ Mean $\mathrm{DPP}=64.885$, means $\mathrm{DMP}=63.385$, mean $\mathrm{DBP}=61.618$, and mean DEP1.748 and was not significant at 0.05 level of significance.

\section{Heavy Metal in Fish}

\section{Discussion}

In this study chromium, cadmium and lead were not detected in all the four fish samples. Nickel was detected only in Clarias gariepinus $\left(\mathrm{HF}_{3}\right)$ with the least concentration of $0.02 \mu \mathrm{g} / \mathrm{g}$ and in Cryrinus carpio at a concentration of $0.03 \mu \mathrm{g} / \mathrm{g}$. The concentration is within the permissible level of USFDA, 1993b of range 70$80 \mathrm{mg} / \mathrm{Kg}$. Zinc was however detected with concentrations between $1.03 \mathrm{ug} / \mathrm{g}$ and $0.68 \mu \mathrm{g} / \mathrm{g}$ in Clarias gariepinus, while Cryrinus carpio had $0.92 \mu \mathrm{g} / \mathrm{g}$ mean concentration. The concentration is within the permissible level of FAO (1983) of $30 \mathrm{mg} / \mathrm{Kg}$.

The statistical analysis on fish shows that there is no significant difference between the means of concentration in the location used $\left(\mathrm{F}_{\text {cal }}=0.371<\mathrm{F}_{\text {tab }}=2.84 . \mathrm{p}>0.05\right)$.

\section{Detection and Quantification of Phthalate Esters in Fish}

In the current study DBP was not detected in both Cyrinus carpio and Clarias gariepinus samples and the detection and the quantification of the four esters is not as the concentrations recorded in the detection and quantification of four phthalate esters such as dimethyl phthalate (DMP), diethyl phthalate (DEP), dibutyl phthalate (DBP), and diethyihexyl phthalate (DEHP) - in water, sediment, and some fish species from the Ogun river catchments, Ketu, Lagos carried out using flame ionization gas chromatography. DMP was not detected in the fish samples. The difference in fish phthalate levels are not statistically significant at $<0.05$, an indication that phthalate esters accumulation is not fish species dependent. The DEP, DBP, and DEHP values recorded are considerably higher than the maximum allowed concentrations for fish prescribed by the US Environmental Protection Agency (Adeniyi et al., 2008).

The result of statistical analysis on fish showed that there was no significant difference between the mean phthalate esters used $\left(\mathrm{F}_{\text {cal }}=1.431<\mathrm{F}_{\text {tab }}=2.84, \mathrm{p}>0.05\right)$. Mean DPP was 64.885, DMP 63.385, DBP 61.618 and DEP 1.748 was not significant at 0.05 level of significance. There was no significant difference between the mean concentration in the locations used and the mean phthalate esters identified.

\section{Conclusion}

Fish samples in the river were contaminated with phthalate esters which may have adverse effect on prolong consumption. This concentration observed is likely introduced by the water and sediment of the river. Therefore, it is recommended that fish grown in this river should not be consumed by the populace. 


\section{References}

[1] Adeniyi, A.A., Okeddeyi, O.O. and Yusuf, K.A. (2008). Assessment of the exposure of two fish metals pollution in the Ogun river catchments, Ketu, Lagos, Nigeria, Environmental Monitoring and Assessment, 137 (1-3), 451-458.

[2] Blount, B.C., Silva, M.J., Caudill, S.P., Needham, L.L., Pirkle, J.L., Sampson, E.J., Lucier, G., Jackson, R.J., and Brock, J.W. (2000). Levels of seven urinary Phthalate matabolites in a human reference population, Environment Health Perspect. 108, 979982.

[3] Censi, P., Spoto, S.E., Saiano, F., Sprovieri, M., Mazzola, S., Nardone.G., DiGeronimo, S.I., Puntro, R. And Ottonello, D., (2006). Heavy metals in coastal water systems. A case study from the north western Gulf of Thailand. Chemosphere, 64, 1167-1176.

[4] Fatoki, O.S. and Vernon, F. (1990). Phthalate esters in the rivers of greater Manchester area, U.K. Science Total Environ., 95, 227232.

[5] Fatoki, O.S. and Ogunfowokan, (2008). Determination of Phthalate Esters plasticisers in the aquatic environment of South Western Nigeria, Environ. Int., 19, 619-623.

[6] Fatoki, O.S. and Noma, A. (2008).Solid Phase Extraction Method for selective determination of Phthalate Esters in the aquatic environment, Earth and Environmental Science Water, Air and Soil Pollution, 140(1-4), 85-98.

[7] Fernandes, C., Fontasnhas, a., Cabral, D. and Salgado, M.A. (2008). Heavy metals in water, sediment and tissues of Liza saliens from Esmoriz-Paramos lagoon, Portugal, Environmental Monitoring and Assessment, 136 267-275.

[8] Mac Farlane, G.B. and Burchett, M.D. (2000). Cellular distribution of $\mathrm{Cu}, \mathrm{Pb}$ and $\mathrm{Zn}$ in the Grey Mangrove Avicemnia marina (Forsk), Vierh AquaticBotanic, 68, 45-59.

[9] Sogiento, S.P. (2008). Concentration and transport data for dissolved inorganic constituents in water collected during seven cruises on the Mississippi River and some of its tributaries, July 1987 - June 1990. US Geological Survey Open-file report 94-524, 102. Wang, W.X. (2002). Interaction of trace metals and different marine food chain, Marine Ecol. Prog. Ser., 243, 295-309. 